\title{
Child with autistic spectrum disorder: care from the family
} Criança com transtorno do espectro autista: cuidado na perspectiva familiar Perspective niño con trastorno del espectro autista: cuidado en la perspectiva familiar

Lina Domenica Mapelli ${ }^{1}$ (C) Mayara Caroline Barbieri ${ }^{1}[$ ]

Gabriela Van Der Zwaan Broekman Castro ${ }^{1}$ (1) Maria Aparecida Bonelli ${ }^{1}$ (1) Monika Wernet ${ }^{1}$ (i) Giselle Dupas ${ }^{1}$ (10

1. Universidade Federal de São Carlos. São Carlos, SP, Brasil.
Corresponding author: Lina Domenica Mapelli. E-mail: mapellilina@gmail.com

Submitted on $04 / 19 / 2018$. Accepted on 09/22/2018.

DOI: 10.1590/2177-9465-EAN-2018-0116

\section{Abstract}

Objective: To know the experience of the family in the care of the child with Autism Spectrum Disorder (ASD) and to discuss possibilities of health care. Method: Descriptive research with qualitative approach, carried out with 15 families of children with ASD, living in two municipalities in the interior of the state of São Paulo, from October 2016 to March 2017. The Symbolic Interactionism was used as theoretical reference, and Narrative Analysis, as method. Results: Families perceive signs of autism, however, believe that there are not suspicious behaviors, but the child's personalities. When diagnosis is defined, family acceptance is painful and sad. The mother shows to be the main caretaker, while the father remains in the background. A significant change of direction of the family towards the care/attention/stimulation of the autistic child is observed. Conclusion: Unveiling family experience in the care of children with ASD amplifies strategies for reinforcement and adaptation.

Keywords: Autistic Disorder; Family; Nursing; Child Care; Child.

\section{Resumo}

Objetivo: Conhecer a experiência da família no cuidado da criança com Transtorno do Espectro Autista e discutir possibilidades de cuidado em saúde. Método: Pesquisa descritiva, qualitativa, realizada com 15 famílias de crianças com Transtorno do Espectro Autista, residentes em dois municípios do interior do estado de São Paulo, no período de outubro de 2016 a março de 2017. Utilizou-se como referencial teórico o Interacionismo Simbólico, e a Análise de Narrativa como método. Resultados: A família percebe sinais do Transtorno do Espectro Autista; entretanto, acredita que não existem comportamentos suspeitos, mas personalidades próprias da criança. Quando o diagnóstico é definido, a aceitação familiar é aflitiva. A mãe demonstra-se cuidadora principal, enquanto o pai permanece na retaguarda. Constata-se um significativo direcionamento da família para o cuidado/atenção/estímulo à criança autista. Conclusão: Desvelar experiência familiar no cuidado da criança com transtorno do espectro autista potencializa estratégias de fortalecimento e adaptação.

Palavras-chave: Transtorno Autístico; Família; Enfermagem; Cuidado da Criança; Criança.

\section{Resumen}

Objetivo: Conocer la experiencia de la familia en el cuidado del niño con Trastorno del Espectro Autista (TEA) y discutir posibilidades al cuidado en salud. Método: Investigación descriptiva con abordaje cualitativo, realizada con 15 familias de niños con TEA, residentes en dos municipios del interior del estado de São Paulo, en el período de octubre de 2016 a marzo de 2017. Se utilizó como referencial teórico el interaccionismo simbólico y como método, el análisis de narrativa. Resultados: La familia percibe signos del autismo, sin embargo, cree que no hay comportamientos sospechosos pero personalidades propias del niño. Cuando el diagnóstico es definido, la aceptación familiar es aflictiva. La madre demuestra un significativo direccionamiento para el cuidado/atención/estímulo al niño autista, mientras el padre permanece en la retaguardia. Conclusión: Revelar la experiencia familiar en el cuidado al niño con TEA potencializa estrategias de fortalecimiento y adaptación.

Palabras clave: Trastorno Autístico; Familia; Enfermería; Cuidado del Niño; Niño. 


\section{INTRODUCTION}

Autism Spectrum Disorder (ASD), or autism, is characterized as a disorder related to neurodevelopment and usually has its manifestation in early childhood. It comprises two domains: one associated with communication difficulties and social interaction; and another related to restrictive and repetitive behaviors. ${ }^{1}$ Its global prevalence is of the order of 10/10,000 children, being superior in the male gender - for each girl, five boys are autistic. ${ }^{2}$

The Brazilian government demonstrates efforts to care for this population and their family, especially in terms of rights, supported by the National Policy for the Protection of the Rights of Persons with Autism Spectrum Disorder, which, among other issues, guarantees early diagnosis, multiprofessional care and access to information that helps in diagnosis and treatment. ${ }^{3}$

The National Agenda for Priorities in Health Research (NAPHR) indicates the need for greater investments in studies related to mental health. ${ }^{4}$ In this sense, it is identified in the health literature recurrence of studies on autism, however few are aimed at exploring the perspective of parents and guardians..$^{1,5}$

The family is the first environment of socialization of the child and the primary context of their care; having the potential to meet their needs, in order to support and promote their development potential. In this perspective, the emergence of a chronic condition and its management within the family interactions are a challenge, which may determine the weakening of family ties and their structure. ${ }^{6}$ In view of the above, the present study takes as a research question: "How does the family experience the care of the child diagnosed with ASD?" The objective is to know the family's experience in the care of children with Autism Spectrum Disorder and to discuss possibilities of health care.

\section{METHOD}

In view of the interest in using the qualitative approach to understand the meaning of experiences and lived situations of social relations, ${ }^{7}$ Symbolic Interactionism (SI) was used as a theoretical reference, being pertinent since it turns to the interaction in which individuals are protagonists, valuing the meaning attributed to their experiences. It is from the social interaction that people relate and know the world in which they are inserted. ${ }^{8}$

Twenty-two participants from 15 families of children diagnosed with ASD were included in the study. We adopted the concept of a child from the Child and Adolescent Statute ("ECA" in Portuguese translation), that is, from 0 to 12 years of age. ${ }^{9}$ The criteria for selecting the participants were: $\left.a\right)$ to be the father, mother or legal responsible for the child with TEA; $b$ ) be over 18 years of age.

Participants were identified from the first letter of the degree of kinship - Mother (M), Father (F) or Sibling (S) - with the child, identified as the index case $(\mathrm{C})$ of the research, followed by the order in which the interview was made.

The survey comprised families from two municipalities in the interior of the state of São Paulo, 14 residents in municipality "A" and one in municipality "B". It should be emphasized that the latter emerged as a potential scenario for locating participants, but by contacting families, it was observed that the age of people with ASD was over 12 years, except one.

The initial invitation to the study came from a group activity with families of autistic children in a health unit of the municipality " $A$ ". After the projection of a film on the theme, there was a round of talk about it and the experiences lived by the families, moment where the study was presented and the participants were invited to take part in it. Of those who expressed interest, the telephone contacts were obtained and, later, the interest was confirmed and the interviews were scheduled.

The semi-structured interview was the data collection strategy, since it allows the obtaining of data of an objective and subjective nature, in which the interviewee has the possibility to narrate about the proposed theme, without answers or conditions prefixed by the researcher. ${ }^{10}$ They were performed in the environment of the family, nine of which took place in the health unit and six at home; with different durations ranging from 45 to 90 minutes, with an average duration of 60 minutes each, from October 2016 to March 2017.

Narrative Analysis was used as method. It is considered that the narratives follow a sequential order, based on the plot, seeking to recapitulate the facts, the characters, the time, the space and the environment of the chronicle. Thus, when analyzing a narrative, a method is used to investigate the subject's intimacy, making public thoughts, feelings and meanings that relate to his own self, as well as the scenarios and characters of his daily life. ${ }^{11}$

The data analysis took place in five stages, first the transcription of the interviews in full was carried out to proceed to the steps of the method: reading and re-reading the data in order to identify the central theme of the narratives; pointing out global impressions; specification of the content focuses to be incorporated for the reconstruction of the story; and a reflexive re-reading with specification of representative sections of the themes. ${ }^{12}$

All the ethical recommendations for research with human beings contained in Resolution No 466/2012 were followed, and the study was approved by Ethics Committee in Research with Human Beings under opinion number 1,710,625.

\section{RESULTS}

The analysis of the data allowed to apprehend two categories and five subcategories. The categories were divided and subdivided based on the similarities of groups of speeches of different participants (Box 1). 
Box 1. Categorization and subcategorization of results

DIAGNOSTIC PROCESS: UNUSUAL BEHAVIORS AND DUAL RELATIONSHIPS

Child Behaviors and Diagnosis

Professionals and diagnostic uncertainty
CARE FOR THE AUTISTIC CHILD: RELATIONSHIPS AND FUTURE PROSPECTS

Care and intra-family relationships

Care and extra-family relationships

Hope in the Path

Source: elaborated by the authors.

\section{DIAGNOSTIC PROCESS: UNUSUAL BEHAVIORS AND DUAL RELATIONSHIPS}

The child's diagnostic trajectory is marked by the interaction of the family with uncommon and somewhat aggressive behaviors of the child, especially when contradicted, and by the duality of opinions of people in their social environment about such behaviors. The way in which the family interprets the symbols expressed by the child with ASD in the interaction with family members and society gives greater meaning to the characteristic behaviors. The SI means that social interaction is symbolic, intentionally emitting symbols when interacting with other people, the difficulty of interaction expressed by the child with ASD directs the family's look at diagnosis.

\section{Child Behaviors and Diagnosis}

The family identifies that certain behaviors of the child, especially in situations where they feel apparent discomfort and/or are opposed, are aggressive and uncommon. The family keeps an eye on the situations where this happens and maintains understanding efforts, in order to identify recurrences of components in the scene. This process effectively signifies meanings in terms of wishes imputed in the manifest behavior that are then considered in the family daily life.

Many of these understandings reveal discomforts in spaces and social practices typical of childhood, with unfolding social interaction for both the child and the family. The social isolation of the family that has a member with chronic disease is frequent; this is due to several reasons: the discovery phase of the disease, the appropriateness of the medications, the recognition of the behaviors, the resilience of the family functioning, the fear of the new, entangled in prejudice and insecurity.

The family coexists with marked behaviors through which it interprets that the child seeks to signal their desires or discomfort in social interactions. The discomfort of intense noise in social spaces and changes in routines were highlighted as poorly tolerated by the child with ASD, integrating evidence that made up the diagnosis. In this direction, they also highlight those related to food, the act of feeding is the focus of mothers in the care of the child, from breastfeeding after birth and during the phases of growth, and this care is a thermometer in physical and emotional well-being of their son. This food care is combined with the early diagnosis of maternal descriptions.
One of the behaviors of $\mathrm{C} 10$ that draws attention is that I can't take him to birthdays, June party, celebration of Mother's Day, because he does not like to stay where there are a lot of people [...] gets annoyed by the noise, runs to hide, strikes his head with the hand and puts his hand to the ear to hear nothing (M10).

At school, C2 does not like to change the routine. Doesn't like when the teacher misses class and is replaced. He also does not like when another classmate sits in his place, moves his material [...] if someone changes what he did, he gets nervous (M2).

He has binge eating when he gets nervous [...]. For example, he has just finished dinner... he opens the cabinets and eats two packets of cookies, it is dangerous for him to eat the whole pack at once (M10).

It is emphasized that the family initially interprets the symbols expressed by the child in the interactions as behaviors typical of the personality and not related to any disorder. With the diagnosis or its suggestibility, the family commits to maintain the care and management of daily life as closely as possible to the 'natural'. There are family members who, even in face of diagnostic confirmation, continue signifying behaviors as related to the child's personality. Given this, the acceptance of the child with his interactional peculiarities is sometimes difficult for some relatives, who avoid close relationships.

Inever suspected any behavior from C15, I always thought it was his personality. When I became familiar with the diagnosis, I did not believe it and thought with me, C15 having autism will not change him at all, caring for him, will be like for the other siblings who do not have any syndrome, they are normal children (M15).

My parents think that $C 4$ has nothing, what he wants is to draw our attention. We talk, explain, but it seems they do not understand that the boy has a problem. So, I don't even go to their house very much [...]. It is bad not to have the child accepted by the grandparents themselves (F4).

The set of behaviors above implies limiting the social participation of the family, which avoids social contexts where the child feels uncomfortable or not accepted. 


\section{Professionals and diagnostic uncertainty}

It is added to the scenario of the family of the child with ASD, the fact of living with health professionals who do not endorse the child's diagnosis, imposing dual professional interactions. Furthermore, there is a contradiction in defining and closing the diagnosis of ASD among these professionals, generating doubts and uncertainties regarding the efficiency of the treatment offered.

\begin{abstract}
After consulting with the autism specialist, I took the papers with the report to the APAE, to show them that C2 had autism, but APAE professionals claim that C2 is not autistic, so he is treated like a normal child. I get confused, I do not know if I believe in the APAE or the specialist (M2).

I took C5 to the neurologist, he looked and said he was autistic, also said that he would perform tests to confirm the diagnosis [...]. In the health care institution that I take C5, there is a doctor who attends him since the age of 6 months that says that $C 5$ is not autistic and that autism is in evidence, if the child is hyperactive or aggressive, is considered autistic. [...] So, it's in this fight between this doctor and the neurologist (M5).
\end{abstract}

\section{CARE FOR THE AUTISTIC CHILD: RELATIONSHIPS AND FUTURE PROSPECT}

Throughout the care of the child with ASD, the family, especially the mother, faces difficulties in meeting the needs of the family, in particular related to the dynamics within the family and access to social rights. Concomitantly to this process, and as a member of the family, the family plans strategies for increasing the autonomy of the child. Prejudice is experienced by the participants of the research with suffering, both intra and extrafamilial, with repercussions on ties of attachment and affection. In spirituality, the family seeks to sustain itself in order to maintain the hope of finding the right care and remain oriented to it.

\section{Care and intrafamilial relationships}

Since the diagnosis of ASD, the mothers participating in this study, the main caregivers, assume responsibility for providing the best care with the child as essentially theirs, with a focus on promoting the expression of the developmental potential of the child. The commitment felt in this role is great, it generates fear in terms of its non-execution entirely or not supporting the requirements inherent to it. To go experiencing this role allows them to affirm that the attitude required is one of careful and continuous vigilance, with the acceptance of organizing the family dynamics taking into account the needs of the child with ASD.
This aspect practically determines a donation on their part and the acceptance of other family members to transfer their needs to a secondary place to the detriment of the child. In this direction, one of the essential aspects is the acceptance of the ASD by the family members, fact that was indicated as not fulfilled for some parents and relatives.

The father assumes limited participation in the life and care of the child. The usual was for him to remain in the background of care and existing weaknesses in the father-son ties, with consequences to the marital bonds.

After C7 was born, I don't any time for myself. From the moment he gets up until bedtime, I have to watch him all the time (M7).

I had to further stimulate the independence of C3, to teach to use the bathroom, to dress alone. These stimuli of independence were far greater than those I made available to his brothers. [...] In addition, I had to show the world to him as it truly is, because to me [...] he is a very innocent child, so I feel the need to explain more to him than to others as the things really work, so he doesn't get fooled (M3).

I am divorced from him (the father of the child), he does not accept the diagnosis of $\mathrm{C} 9$ at all, he says that what C9 does is child tantrum, that what is missing it to teach the basics... he cannot understand the behaviors are characteristic of autism and not to draw attention. The father of $\mathrm{C} 9$ picks him up here at home and then returns him because he says he cannot take care of by himself (M9).

In the face of ASD, it is common to have doubts about the situation and one of the resources used by the family, to clarify doubts and obtain more information, was the internet. For some families this resource contributed to discoveries about autism and brought together family members, with a consequent increase in the child's understanding and the particularity of the child's situation, as well as greater participation in the child's care.

The C6's aunt said that autism was a serious disease, which may have had no cure. So, I went searching on the internet more about autism. I have found that the autistic child has his head and his world, which are systematic and most of the time, stay in their world. In addition, there are categories of autism, there is the mild, moderate and severe (F6).

I started researching the internet about autism, so I was talking to C4's grandfather about autistic behaviors. $\mathrm{He}$ realized that $C 4$ did everything he was talking about on Facebook. From that moment, we began to understand what autism was (M4). 
In the search for intrafamilial support for the care of the child, the mother appreciates the potential in people on how much there is understanding of the situation, affective and committed involvement with the child. The usual in this study was the maternal grandmother.

My mother helps me a lot with C11, I trust her taking care of him, if I have to leave and I cannot take him, the first person I think is of her, I owe a lot to her (M11).

Still in relation to the family dynamics, in the existence of other children, the mother had to deal with the comparisons they made regarding the treatment and attention received by the child with ASD. The interpretation of the other children was that there was an excessively high attention and care to the child with ASD, when jealousy manifestations were common.

I believe I have to pay more attention to C12, to stimulate him to speak and to do the lessons in school. I feel that $S 12$ feels quite jealous of $C 12$ because he tells me that when C12 does something wrong, I don't call his attention (M12).

On the other hand, relationships in the family nucleus are signified as of empowering the child with ASD to cope with the wider social relations. The intentional use of relations with the brother, with a view to preparing for the broader relations in society, is made explicit in the following speech.

After the diagnosis, I started to insert $S 1$ in the games at home so that it encourages the interaction with the brother. If this interaction with the sibling occurs in a healthy way, I believe it will be easier to interact with school friends (M1).

The process of caring for the child with ASD brings learning to the woman in terms of values and respect for the singularity, with consequences to intra and extrafamilial relations.

C11 taught me a lot, like being calmer and having more patience with other people. Before being a mother, I had no patience, after I had them, especially C11, I learned to have. I also learned that each person has their time, that not everyone accepts autism, that there is a lot of prejudice of the population. $\mathrm{C} 11$ showed that I needed to be more careful with my children, who are children and need an adult supervising the playing and lessons at school (M11).

\section{Care and extrafamilial relationships}

In the broader social relations, the family describes difficulties of inclusion of the child with ASD in the society, when feelings of exclusion and prejudice reverberate in situations of contempt and social rejection, with denials to rights as access to education, religion, health, leisure and well-being. In the face of them, the mother needs to put up resistance and demand rights.

To put $C 4$ in the catechism was a struggle, because the priests of the church wanted me to put him in the APAE and that the teachers went there to teach him, I think that was a bit of prejudice (M4).

I realized it when I took C11 to school that the teacher treated all the students with affection, except $C 11$. She told me that I would have to wait for his caretaker on the patio or at the principal's office, sort of pulling me out of the classroom. I believe that for my son having autism, she also made a kind of exclusion with me (M11).

There is clear maternal concern about the future social reception of the child with ASD, especially when they ponder their non-eternal presence in their life and the effects of social prejudice they feel. In view of this, they seek investments in the autonomy of the child, whether investing in stimulus and education, or in terms of 'lucidity'/performance, aspect that the medications common to the treatment of ASD are very limited.

I do not expect C5 to be dependent on medicine all life, I want to see him happy without being doped, I wish C5 has a future with success (M5).

The only fear I have of the future is to die and leave C14 helpless. I do not know how he will be in the future, if anyone can look out for him, if he will face prejudice (M14).

I want to do everything so that he can continue to study, be able to go to a college, to show people that it is not because he has autism, that the child has to live closed at home, not being able to build his own life (M10).

In the relations with the different health teams and professionals typical of the trajectory of families with children with ASD, it was the psychologists, psychopedagogues and speech therapists who emerged as more welcoming. There was sensitivity, interest and involvement of the same in contributing to the uniqueness of the needs of the child and family, effecting with protection to social rights in the adverse territory marked by prejudice and denial of access.

The speech therapist is my guardian angel, my center of reference [...] is the one who supported me from the beginning, helped with school and family. So, I consider her as part of my family. The psychologist is also always present, they are fundamental for C8's care. C8 also has a passion for the psychopedagogue, which as the 
speech therapist is a formidable professional. The psychopedagogue also provides $C 8$ with all the attention needed in education; in addition, she participates daily in the personal life of $\mathrm{C} 8$ (M8).

Another social resource that is effective as support are groups of families in a situation similar to theirs. In these spaces, the sharing of experiences, both good and bad, lead to confrontations, ways of dealing with the misfortunes of the path of diagnosis and care of the child with ASD. It is important to highlight the relevance of this resource at the time of diagnosis, as well as the recognition of these social spaces where the support occurred. They conceive it as a space where resilience takes place, as well as the social struggle for improvements in the diagnosis, treatment and quality of life of the child with ASD and their families. Taking this into consideration, they point out the need for disclosure and guarantee of the same.

I think it is important for city hall to further publicize the support group of mothers and fathers of autistic children. There are many mothers who are diagnosed, don't have the internet to look for information. These mothers are generally humble and do not know about the group and don't have the support of other mothers in the same situation (M3).

When I heard about the diagnosis, I started to cry, and I was desperate. The mother of $C 3$ was with me and began to comfort me saying that I was not the only one in the world that had an autistic child, that more people could support me in the municipality (M9).

\section{Hope in the Path}

Still in the scenario of coping and resilience, the family seeks the strengths to deal with difficulties and misfortunes inherent to the care of the child with ASD. Spirituality, more specifically God, and the belief in the revelation of the path and the strength and protection to walk are effective as a resource that keeps the families oriented to continue in the care.

I ask God to enlighten my path, because if my mission is to be the mother of C9, let Him give me strength to go through all the obstacles that are placed in it (M9).

I think that more than going to church, asking God for protection, asking Him to light the paths we will cross during our lives, is the most helpful (M13).

\section{DISCUSSION}

The family of the child with ASD experiences a dynamic process in which the members mobilize themselves taking active roles in the face of signs, diagnosis and care, where their interpretations of the situations lived, as well as the interactions with the child, direct the actions performed by them.

Signs of autism are perceptible to parents before the second year of life, with deficits in communication and social interaction being the first to be recognized as altered. ${ }^{13}$ Behaviors linked to repetition and restriction of activities as well as aggression are common to autistics. ${ }^{14}$ The autistic child has difficulty communicating with family and community, culminating in limits to the expression and understanding of desires. These results are in agreement with studies that affirm that there are fragilities of understanding in the social interactions between the autistic, their family and the means of conviviality. ${ }^{15}$

Another trigger of suspicion that the child has needs that require to be better investigated is the challenging behavior at mealtimes due to dietary restrictions and compulsions; there is a concern with nutritional status and quality of life, due to the high selectivity of food.$^{16}$ In addition to these characteristics, in followups of children's growth and development, reports from families in this direction must be valued and exploited by professionals with a view to early diagnosis.

It is difficult to carry out the early diagnosis of ASD as a result of the preparation of professionals in the health care network. ${ }^{17}$ The family experiences uncertainties during this process, which often leaves them insecure in relation to the proposed therapeutic conduction.

The difficulty in accepting the diagnosis is externalized by the family through the feeling of guilt, denial, insecurity and hopelessness for the loss of the child considered "normal" in the eyes of society. ${ }^{18}$ However, this study revealed the mothers' commitment to provide the best care, including in terms of stimulating the development of the child's potential.Thus, having ready access to social equipment that can provide guidelines and therapeutics in this direction is essential to enhance maternal and family orientation in order to promote the possible autonomy of the child with ASD.

On the other hand, it is common for families to pass through various specialists, with the false hope that they will not receive confirmation of the diagnosis. This pilgrimage happens until the family finally accepts it, deciding to adhere to the appropriate treatment, bringing long-term benefits to their quality of life..$^{18,19}$ One of the issues that contribute in this direction, as revealed in this study, is the duality of opinions about the diagnosis that families experience in interactions with health professionals.

It is essential that health professionals who monitor growth and development know and keep up-to-date on the diagnostic guidelines for ASD, so that the issuance of their opinions on the situation of the child can contribute to the best therapeutic process, which will certainly generate greater family security. In addition, the care network becomes effective when the professionals communicate with each other. No family in this study reported efforts by professionals to discuss the child's situation and to make joint therapeutic plans. 
The results, reminiscent of the changes and care taken after diagnosis, show the possibility of expression of positive aspects such as conflict relief, ideas exchange, teaching and intrafamilial union. The positive changes that took place in the lives of the families interviewed gave them renewing, comforting and continuous values and meanings, impacting on the strengthening of the bonds between their members.

The roles played by the mother and father are rooted in the family nucleus of the interviewees; to the mother it is allowed to play the role of primary caregiver, while the father remains in the background, assuming responsibility for the financial support of the home. Mothers suffer significantly from feelings of fear, guilt, and increased demand for care. ${ }^{20,21}$ while the father is reflected by the non-acceptance of the diagnosis. ${ }^{18}$ Thus, including the father in the follow-up consultations on child growth and development, especially those with ASD is an urgent need, with unfolding to the family dynamics. There are labor issues that limit the effectiveness of this insertion.

Faced with this, there is a need for social struggles that sensitize policy makers in regard to this. Another movement is to expand the evidence on the benefits of the insertion of the father of children with ASD and/or other chronic diseases in the follow-up consultations of child growth and development. However, it should be emphasized that the effectiveness of this intervention depends on the health professional actually delivering care that includes the family, with an interest in their doubts and experiences in the care of their child. The absence of a relational space that favors the family to expose their afflictions and dynamics devoid of power and results an insertion of this nature. We recommend studies in this direction.

Another intrafamilial situation, which could be better accommodated with the same inclusive logic, would be jealousy between siblings in the context of ASD. The sibling child needs space to expose his or her perception of family dynamics, and health professionals could guarantee this space, whether in consultation with his or her sibling, or both. The overprotection given to children with ASD is described as typical to family dynamics and causes jealousy in the sibling child. ${ }^{18}$

Involving extrafamilial situations, related to the relational context of autistic children and their families, we have the prejudice suffered in different social environments. Authors reinforce that prejudice and victimization of the autistic child provide parents with episodes of stress and social conflicts to be overcome by them. ${ }^{22}$

In the search to overcome prejudice, we observe, in our study, the expectation of the mother to see the child with greater independence and somehow inserted in the society. Research performed with a child diagnosed with Asperger's syndrome observed that the family is an essential tool in the process of acquiring their autonomy. There is a dichotomy in the family's decisions regarding the treatment of autism. The family predicts independence of the child, but the medication seems to be limiting autonomy, as sleepiness increases, minimizes critical sense and ability to discern. ${ }^{23}$

Drug therapy is seen as limiting infant expression. In contrast, antipsychotic drugs such as Risperidone are commonly prescribed for individuals with ASD, relieving aggressive behavior/ irritability and promoting social skills development, with a recurrent side effect of increased appetite and body weight. ${ }^{24}$

In association with drug therapy, behavioral therapies, motor and cognitive skills development stimuli, communication strategies, directed by physiotherapists, speech therapists, occupational therapists and psychologists are used. The treatment of autistic children is based on the early diagnosis integrated with the other therapies, contributing to the positive prognosis of ASD. ${ }^{25}$

Integrative practices can be used as propellants for the happiness of autistic children, highlighting their interest in music. The beneficial result of music therapy contributes to the development of social and communicative skills of the studied children. ${ }^{26}$ Spirituality conceives the support capable of bringing sustenance to everything that is above the competence of the human being; belief in a superior being conveys strength and courage to overcome the obstacles imposed by autism deficits. ${ }^{27}$

An important strategy to be used as social support, the internet, has been connecting individuals with common interests, functioning as a space for information exchange, claims and support among its users, capable of influencing people's daily lives and their attitude towards autism. ${ }^{28}$

Nursing professionals should pay attention to the singularities of individuals and their respective needs, providing quality and integral care that meets all the demands of autistic care and their families, contributing to the strengthening and extension of their relational ties..$^{19,29}$ The nurse involved, due to his/her competence in caring for the patient and his/her family, is a professional capable of inserting himself/herself in the home care and contributing with the family in the organization of the family dynamics and care.

Each family has particular needs, where the fragilities to be covered are related to family dynamics. It is necessary to understand the family, its structure and functioning, and it is up to the professional to discover, through consultations, narratives, and, mainly, to understand in the home environment how the family organization, relationships and resilience occur. In this sense, home visits can be part of the planning of home care, since they reveal other issues that the office space/health institution does not cover.

The family demands care provided by professionals from different areas; it is observed that each professional act within their own attribution, in isolation, even though they belong to the same treatment team. In this way, the support offered is discontinuous and disproportionate to cover all the needs of the family. ${ }^{30}$ 
The ability of the health professional to place himself in the "other's place", a concept of SI present in established interactions, can open doors to increase the interaction with the family and, consequently, the possibility of generating care from the conception of who effectively takes care of. Still regarding this concept, taking on the role of the other is a task that begins in childhood which helps the child to improve the Self and act in society. The "child with ASD" may or may not succeed in assuming the role of the other, depending on the degree of the disorder and the capabilities experienced both intra and extrafamilial.

\section{FINAL CONSIDERATIONS AND IMPLICATIONS FOR PRACTICE}

The realization of this study made it possible to reach the objective of knowing the experiences lived by families of children with ASD. Among the various struggles undertaken by the family, the initial one is related to the establishment of the diagnosis, in which the various behavioral evidences do not always lead to an early diagnosis. After this phase, the relational difficulties stand out, impacting both in the family and in the external interactions with it, as well as with other family members, health professionals and society as well as with institutions. The presence of prejudice in the interactions is significant, but there is space for manifestations of solidarity and partnership to occur; based on spirituality comes the hope of having strength for the path.

In order to minimize perceived prejudices in care that limit how people relate to the family and the child, professional updating is necessary in terms of information and behavior in the face of ASD. Sharing current knowledge about the ASD with the lay and professionalized public, as well as raising awareness of the family and its effort against the chronic condition, demonstrates to society the possibility of greater contributions of being a participant through care, and can be a potentiation of the effort already exercised by the family.

It is suggested to conduct research with families that have a member with adult ASD to evaluate how aspects of autonomy and independence of the individual are established. It is hoped that this study may contribute to the performance of nurses who deal with autistic children and their families, signaling the need to seek the improvement of care strategies that enable the rescue and expansion of the family unit.

\section{FINANCING}

National Council of Scientific and Technological Development for the financing of an institutional scholarship of scientific Initiation/UFSCAR - 2016/2017.

\section{REFERENCES}

1. Ministério da Saúde (BR). Secretaria de Atenção à Saúde Departamento de Ações Programáticas Estratégicas. Diretrizes de Atenção à Reabilitação da Pessoa com Transtornos do Espectro do Autismo (TEA). Brasília (DF): Ministério da Saúde; 2014. [cited 2016 Mar 31]. [Internet]. Available from: http://bvsms.saude.gov.br/bvs/ publicacoes/diretrizes_atencao_reabilitacao_pessoa_autismo.pdf

2. Santos ALV, Fernandes CF, Santana LTG, Santo LRE, Lafetá BN. Diagnóstico precoce do autismo: dificuldades e importância. Rev Norte Min Enferm [Internet]. 2015; [cited 2016 Mar 16]; 4(no.spe):23-4. Available from: http://www.renome.unimontes.br/index.php/renome/ article/view/15

3. Lei no 12.764, de 27 de dezembro de 2012 (BR). Institui a Política Nacional de Proteção dos Direitos da Pessoa com Transtorno do Espectro Autista; e altera o § 30 do art. 98 da Lei no 8.112, de 11 de dezembro de 1990. Brasília (DF): Diário Oficial da União;2012 [Internet]. 2012 Dec; [cited 2016 Mar 21]. Available from: http://www.planalto.gov. br/ccivil_03/_ato2011-2014/2012/lei/l12764.htm

4. Ministério da Saúde (BR). Agenda Nacional de Prioridades de Pesquisa em Saúde. Brasília (DF): Secretaria de Ciência, Tecnologia e Insumos Estratégicos. Departamento de Ciência e Tecnologia. $2^{\underline{a}}$ ed. Brasília (DF): Ministério da Saúde; 2015 [Internet]. [cited 2018 Feb 7]. Available from: http://brasil.evipnet.org/wp-content/uploads/2017/07/ANPPS.pdf

5. Meimes MA, Saldanha HC, Bosa CA. Adaptação materna ao transtorno do espectro autismo: relações entre crenças, sentimentos e fatores psicossociais. Psico (Porto Alegre) [Internet]. 2015 Oct/Dec; [cited 2018 Feb 7]; 46(4):412-22. Available from: http://pepsic.bvsalud.org/ pdf/psico/v46n4/02.pdf

6. Ministério da Saúde (BR). Conselho Nacional do Ministério Público. Atenção Psicossocial a Crianças e Adolescentes no SUS: Tecendo Redes para Garantir Direitos. Brasília (DF): Ministério da Saúde; 2014 [Internet]. [cited 2016 Mar 21]. Available from: http://bvsms.saude.gov. br/bvs/publicacoes/atencao_psicossocial_criancas_adolescentes_ sus.pdf

7. Minayo MCS. Cientificidade, generalização e divulgação de estudos qualitativos. Ciênc Saúde Coletiva [Internet]. 2017; [cited 2017 Aug 20]; 22(1):16-7. Available from: http://www.redalyc.org/ pdf/630/63049169004.pdf

8. Gabatz RIB, Schwartz E, Milbrath VM. O interacionismo simbólico no estudo da interação da criança institucionalizada com seu cuidador. Invest Qualitat Saúde [Internet]. 2016; [cited 2017 Sep]; 2:366-75. Available from: https://proceedings.ciaiq.org/index.php/ciaiq2016/ article/view/773

9. Lei № 8069 , de 13 de julho de 1990 (BR). Dispõe sobre o Estatuto da Criança e do Adolescente e dá outras providências. Brasília (DF): Diário Oficial da União; 1990 [Internet]. [cited 2016 Mar 21]. Available from: http://www.planalto.gov.br/CCivil_03/Leis/L8069.htm

10. Minayo MCS, Deslandes SF, Cruz Neto O, Gomes R. Pesquisa social: teoria, método e criatividade. 33aㅡ ed. São Paulo: Hucitec-Abrasco;2013.

11. Castellanos MEP. A narrativa nas pesquisas qualitativas em saúde. Ciênc Saúde Coletiva [Internet]. 2014 Apr/Jun; [cited 2016 Mar 16]; 19(4):1065-76. Available from: http://www.redalyc.org/ pdf/630/63030543007.pdf

12. Lieblich A, Tuval-Mashiach $R$, Zilber T. Narrative research: reading, analysis and interpretation. Newbury Park: Sage; 1998.

13. Zanon RB, Backes B, Bosa CA. Identificação dos primeiros sintomas do autismo pelos pais. Psic Teor Pesq [Internet]. 2014 Jan/Mar; [cited 2017 May 17]; 30(1):25-33. Available from: http://www.scielo.br/scielo. php?script=sci_arttext\&pid=S0102-37722014000100004

14. Seregen L, Françozo MFC. As vivências de mães de jovens autistas Psicol Estud [Internet]. 2014 Jan/Mar; [cited 2017 May 15]; 19(1):39-46. Available from: http://www.scielo.br/scielo.php?script=sci_arttext\&pid $=$ S1413-73722014000100006 
15. Hamer BL, Manente MV, Capellini VLMF. Autismo e família: revisão bibliográfica em bases de dados nacionais. Rev Psicopedag [Internet]. 2014; [cited 2017 May]; 31(95):169-77. Available from: http://pepsic.bvsalud.org/scielo.php?script=sci_arttext\&pid =S0103-84862014000200010

16. Nunes MRA, Paiva ALC, Marques RCP. Educação inclusiva: uso de cartilha com considerações sobre a alimentação do autista. Includere [Internet]. 2016; [cited 2017 May 16];2(2):114-8. Available from: https:// periodicos.ufersa.edu.br/index.php/includere/article/view/6001

17. Guareschi T, Alves MD, Naujorks MI. Autismo e políticas públicas de inclusão no Brasil. J Res Spec Educ Needs [Internet]. 2016; [cited 2017 May 16]; 16(1):246-50. Available from: https://onlinelibrary.wiley.com/ doi/epdf/10.1111/1471-3802.12286

18. Pinto RNM, Torquato IMB, Collet N, Reichert APS, Souza Neto VL, Saraiva AM. Autismo infantil: impacto do diagnóstico e repercussões nas relações familiares. Gaúcha Enferm [Internet]. 2016 Sep; [cited 2017 May 17]; 37(3):e61572. Available from: http://www.scielo.br/pdf/rgenf/ v37n3/en_0102-6933-rgenf-1983-144720160361572.pdf

19. Silva MEA, Moura FM, Albuquerque TM, Reichert APS, Collet N. Rede e apoio social na doença crônica infantil: compreendendo a percepção da criança. Texto Contexto Enferm [Internet]. 2017; [cited 2017 May 21]; 26(1):e6980015. Available from: http://www.scielo.br/pdf/tce/v26n1/ pt_0104-0707-tce-26-01-e6980015.pdf

20. Joosten AV, Safe AP. Management strategies of mothers of schoolage children with autism: implications for practice. Aust Occup Ther J [Internet]. 2014 Aug; [cited 2018 Feb 5]; 61(4):249-58. Available from: https://www.ncbi.nlm.nih.gov/pubmed/24499184

21. Findler L, Klein Jacoby A, Gabis L. Subjective happiness among mothers of children with disabilities: The role of stress, attachment, guilt and social support. Res Dev Disabil [Internet]. 2016 Aug; [cited 2018 Feb 10]; 55:4454. Available from: https://www.ncbi.nlm.nih.gov/pubmed/27037989

22. Vargas RM, Schmidt C. Envolvimento parental e a inclusão de alunos com autismo. Acta Scientiarum Education [Internet].2017 Apr/Jun; [cited 2017 May]; 39(2):207-14. Available from: http://periodicos.uem.br/ojs/ index.php/ActaSciEduc/article/view/26423

23. Rodrigues PMS, Albuquerque MCS, Brêda MZ, Bittencourt IGS, Melo GB, Leite AA. Self-care of a child with autism spectrum by means of
Social Stories. Esc Anna Nery [Internet]. 2017; [cited 2018 Feb 4]; 21(1):e20170022. Available from: http://www.scielo.br/pdf/ean/v21n1/ en_1414-8145-ean-21-01-e20170022.pdf

24. Aman M, Rettiganti M, Nagaraja HN, Hollway JA, McCracken J, McDougle CJ, et al. Tolerability, Safety, and Benefits of Risperidone in Children and Adolescents with Autism:21-Month Follow-up After 8-Week Placebo-Controlled Trial. J Child Adolesc Psychopharmacol [Internet] 2015 Aug; [cited 2018 Feb 26]; 25(6):482-93. Available from: https:// www.ncbi.nlm.nih.gov/pmc/articles/PMC4545698

25. Monteiro AF, Pimenta RA, Pereira SM, Roesler H. Considerações sobre critérios diagnósticos de transtorno do espectro autista, e suas implicações no campo científico. Do Corpo Ciênc Arte [Internet]. 2017 [cited 2018 Feb 5]; 1(7):87-97. Available from: http://ucs.br/etc/revistas/ index.php/docorpo/article/view/5956/3198

26. Broder-Fingert S, Feinberg E, Silverstein M. Music Therapy for Children With Autism Spectrum Disorder. JAMA [Internet]. 2017 Aug; [cited 2018 Feb 11]; 318(6):523-4. Available from: https://www.ncbi.nlm.nih.gov/ pubmed/28787492

27. Liu EX, Carter EW, Boehm TL, Annandale MH, Taylor CE. In Their Own Words: the place of faith in the lives of young people with autism and intellectual disability. Intellect Dev Disabil [Internet]. 2014 Oct; [cited 2018 Feb 4]; 52(5):388-404. Available from: https://www.ncbi.nlm.nih. gov/pubmed/25247730

28. Ries IL, Demeterco IC. 2 de Abril e a Conexão Azul: o uso da tecnologia como experiência comunicacional e cultural entre grupos que vivem o autismo. Temática [Internet]. 2017; [cited 2017 May 22]; 13(2):237-52. Available from: http://periodicos.ufpb.br/index.php/tematica/article/ view/33013/17148

29. Araújo YB, Reichert APS, Vasconcelos MGL, Collet N. Fragilidade da rede social de famílias de crianças com doença crônica. Rev Bras Enferm [Internet]. 2013; [cited 2017 May 24]; 66(5):675-81. Available from: http://www.scielo.br/scielo.php?script=sci_arttext\&pid $=$ S0034-71672013000500006

30. Barbosa TA, Reis KMN, Lomba GO, Alves GV, Braga PP. Rede de apoio e apoio social às crianças com necessidades especiais de saúde. Rev Rene [Internet]. $2016 \mathrm{Jan} / \mathrm{Feb}$; [cited $2018 \mathrm{Feb}$ 10]; 17(1):60-6. Available from: http://www.periodicos.ufc.br/rene/article/viewFile/2606/1994 